\section{Mechanism of Decreased Vascular Reactivity to Angiotensin II in Conscious, Potassium-deficient Rats}

\author{
Mark S. Paller, Janice G. Douglas, and Stuart L. Linas \\ Departments of Medicine, University of Colorado, Denver, \\ Colorado 80262; Case Western Reserve University, \\ Cleveland, Ohio 44106
}

A

bstract. Chronic potassium deficiency in the rat results in a decrease in the pressor sensitivity to exogenous angiotensin II (AII). To define the mechanism of this resistance to AII, studies were performed in conscious rats after 14-21 d of dietary potassium deficiency. The pressor response to graded doses of AII was $50 \%$ less in potassium-deficient than control animals. In contrast, the pressor response to graded doses of norepinephrine was preserved in potassium-deficient rats; therefore, the decreased response to AII was not due to a generalized defect in vascular reactivity. Pretreatment with either the converting enzyme inhibitor, teprotide, or the prostaglandin synthesis inhibitor, indomethacin, failed to normalize the response to AII. Thus, neither prior receptor occupancy with endogenous AII nor the presence of vasodilatory prostaglandins caused the decreased AII response in potassium deficiency. Since the pressor response to AII involves angiotensin interaction with its vascular receptor, binding studies of mesenteric artery and uterine smooth muscle AII receptors were performed. Scatchard analysis showed that potassium deficiency resulted in a decrease in binding affinity $\left(50 \%\right.$ increase in $\left.K_{d}\right)$ in both uterine (6.00 vs. $3.82 \mathrm{nM} ; P<0.05)$ and vascular $(1.39$ vs. $0.973 \mathrm{nM} ; P<0.005)$ smooth muscle. Furthermore, despite increased circulating AII, there was an increase

Portions of this work were presented at the 14th Annual Meeting of the American Society of Nephrology, Washington, DC, 22-24 November, 1981.

Dr. Douglas is the recipient of the U. S. Public Health Service Research Career Development Award HL00399. Dr. Paller's present address is the Department of Medicine, University of Minnesota, Minneapolis, MN 55455.

Received for publication 25 May 1982 and in revised form 26 September 1983.

J. Clin. Invest.

(C) The American Society for Clinical Investigation, Inc.

0021-9738/84/01/0079/08 \$1.00

Volume 73 , January $1984,79-86$ in AII receptor number in potassium-deficient uterine ( 308 vs. $147 \mathrm{fmol} / \mathrm{mg}$ protein; $P<0.005$ ) and vascular (470 vs. $316 \mathrm{fmol} / \mathrm{mg}$ protein; $0.05<P<0.1)$ smooth muscle. Although potassium deficiency resulted in alterations in receptor-binding parameters, the changes in binding affinity and number were directionally opposite, so that in potassium deficiency there was either no change or an increase in total AII binding. We conclude that the decrease in angiotensin pressor sensitivity in potassiumdeficient rats is mediated by a postreceptor defect since it occurs subsequent to the binding of AII to its vascular smooth muscle receptor.

\section{Introduction}

Chronic potassium deficiency in the rat results in marked changes in plasma renin activity (PRA) 1 (1,2) and in systemic hemodynamics $(3,4)$. After 2 wk of dietary potassium deficiency, PRA is increased threefold (4). Despite this increase in PRA, mean arterial pressure is decreased as the consequence of a $30 \%$ reduction in systemic vascular resistance (4). These observations suggest that there is resistance to the pressor effect of endogenous angiotensin II (AII). In addition to being resistant to endogenous AII, potassium-deficient animals have a decreased pressor sensitivity to exogenous angiotensin (5-9). There are at least five possible mechanisms by which potassium deficiency might alter vascular sensitivity to exogenous AII: (a) a generalized decreased ability of the vascular smooth muscle to react to pressor stimuli, (b) a defect in vascular reactivity caused by changes in sodium balance, $(c)$ prior occupancy of vascular AII receptors by high circulating levels of endogenous AII that prevents receptor binding of exogenous AII, $(d)$ endogenous vasodilators, such as prostaglandins, attenuate the pressor response to AII, and (e) a change in vascular AII receptor affinity, number, or both decreases receptor binding of AII. The purpose of the present study was to determine which of these mechanisms mediates the decreased

1. Abbreviations used in this paper: AI, angiotensin I; AII, angiotensin II; D5/W, 5\% dextrose in water; MAP, mean arterial pressure; PRA, plasma renin activity. 
sensitivity to the pressor action of AII in the conscious potassiumdeficient rat.

\section{Methods}

Studies were performed in both male and female Sprague-Dawley rats (Charles River Breeding Laboratories, Inc., Wilmington, MA) which weighed 190-250 $\mathrm{g}$ at the initiation of the study. Experimental animals were fed a potassium-deficient diet (ICN Nutritional Biochemicals, Cleveland, $\mathrm{OH}$ ) containing $\mathrm{Na}, 150 \mathrm{meq} / \mathrm{kg} ; \mathrm{K}, 10 \mathrm{meq} / \mathrm{kg} ; \mathrm{Cl}, 620$ $\mathrm{meq} / \mathrm{kg} ; \mathrm{Ca}, 4.7 \mathrm{~g} / \mathrm{kg} ; \mathrm{P}, 1.8 \mathrm{~g} / \mathrm{kg}$; and $\mathrm{Mg}, 3.8 \mathrm{~g} / \mathrm{Kg}$, for $14-21 \mathrm{~d}$. Control rats were fed an identical diet to which had been added $\mathrm{KCl}$ and $\mathrm{K}_{2} \mathrm{PO}_{4}$ to yield a final content of $\mathrm{Na}, 160 \mathrm{meq} / \mathrm{kg} ; \mathrm{K}, 240 \mathrm{meq} / \mathrm{kg} ; \mathrm{Cl}, 740$ $\mathrm{meq} / \mathrm{kg} ; \mathrm{Ca}, 4.2 \mathrm{~g} / \mathrm{kg} ; \mathrm{P}, 5.9 \mathrm{~g} / \mathrm{kg}$, and $\mathrm{Mg} 3.9 \mathrm{~g} / \mathrm{kg}$. Rats had free access to food and water.

Plasma for $\mathrm{Na}$ and $\mathrm{K}$ measurements from six control and ten potassium-deficient rats was obtained through femoral catheters and measured on a flame photometer (model 343, Instrumentation Laboratory, Lexington, MA). Plasma renin activity was determined by radioimmunoassay (10) in eight potassium-deficient and six control rats after sacrifice by decapitation.

\section{Hemodynamic studies}

Animals were anesthetized with ether, and polyethylene catheters (PE50 ) were placed in the femoral artery and vein for direct arterial pressure monitoring and drug administration, respectively. During surgery (10 $\min$ ), rats were given volume replacement of $0.5 \%$ body weight with isotonic saline. After surgery, animals were placed in restraining cages and allowed to recover in a quiet room for a minimum of $60 \mathrm{~min}$ before the initiation of any further protocol.

\section{AII dose response}

Pressor dose-response studies were performed by administering an intravenous bolus of AII (Hypertensin-Ciba, Ciba-Geigy, Basle, Switzerland) in doses of $12.5,25,50$, and $100 \mathrm{ng}$ to eight potassium-deficient and eight control rats. A separate group of seven potassium-deficient and six control rats were given lower doses of AII $(1,2.5,5$, and $12.5 \mathrm{ng})$ in an attempt to determine whether the threshold dose for pressor response was different in the two groups of rats. Stock solutions were made monthly and final dilutions prepared daily by using $5 \%$ dextrose in water (D5/ $\mathrm{W})$ so that the volume of injectate was no more than $0.1 \mathrm{ml} / \mathrm{dose}$. Each drug bolus was followed by injection of $0.1 \mathrm{ml} \mathrm{D5/W}$ to flush the venous catheter. Mean arterial pressure (MAP) was measured with a Bell \& Howell pressure transducer (type 4-327-I Bell \& Howell Co., Pasadena, $\mathrm{CA}$ ) and recorded on a polygraph (Gilson Medical Electronics, Inc., Middletown, WI). Preliminary experiments showed that the rise in pressure after injection of $0.2 \mathrm{ml} \mathrm{D5} / \mathrm{W}$ (blank) was $<1.9 \mathrm{mmHg}$ in both control and potassium-deficient animals. A period of $10 \mathrm{~min}$ was allowed between doses, and all animals studied returned to base-line MAP before administration of the next dose of pressor agent. By utilizing this protocol, preliminary studies demonstrated reproducible pressor response in individual animals to the same dose of AII or norepinephrine when repeated up to four times.

\section{Norepinephrine dose response}

By using a protocol similar to that described for AII, studies of dose response to norepinephrine were performed in eight potassium-deficient and six control animals. Intravenous bolus doses of norepinephrine (levarterenol bitartrate, Sterling Drug, NY) of 50, 100, 200, and $400 \mathrm{ng}$ were employed.

\section{Angiotension dose response after converting enzyme inhibition}

To determine whether the decreased pressor sensitivity to exogenous AII was caused by prior occupancy of AII vascular receptors with endogenous AII, the pressor response to AII was determined $10 \mathrm{~min}$ after administration of the angiotensin-converting enzyme inhibitor, teprotide (SQ20, 881, E. R. Squibb \& Sons, Princeton, NJ), to eight potassiumdeficient and eight control rats. Because the half-life of circulating AII is short, prevention of synthesis of AII by converting enzyme inhibition allows the testing of the vascular response to exogenous AII in the absence of receptor occupancy with the endogenous hormone. Teprotide was administered as a $1 \mathrm{mg} / \mathrm{kg}$ intravenous bolus followed by continuous infusion of $1 \mathrm{mg} / \mathrm{kg} / \mathrm{min}$. The adequacy of converting enzyme inhibition was ascertained by determining the pressor response to $50 \mathrm{ng}$ of angiotensin I (AI) before and $10 \mathrm{~min}$ after the administration of teprotide. All animals studied had a decrease in the pressor response to AI of at least $85 \%$. In the presence of converting enzyme blockade, the pressor response to AII was determined by using the above protocol. $10 \mathrm{~min}$ after the last dose of AII, the adequacy of converting enzyme inhibition was again determined. To be certain that the administration of converting enzyme inhibitor was capable of freeing vascular receptors of endogenous AII, dose-response studies to AII were also performed before and after converting enzyme inhibition in four rats fed a sodium-deficient diet for $7 \mathrm{~d}(11)$.

\section{Angiotensin dose response after prostaglandin synthesis inhibition}

To determine the effect of prostaglandin synthesis inhibition on AII sensitivity, six potassium-deficient and six control animals were pretreated with indomethacin, $5 \mathrm{mg} / \mathrm{kg}$ i.p., $2-3 \mathrm{~h}$ before studies of dose response to AII. This dose of indomethacin has been shown in our laboratory to decrease 8-h urinary prostaglandin $E_{2}$ excretion by $87 \%$ in both potassium-deficient and control rats (4).

\section{Receptor binding studies}

Preparation of tissue. Studies of receptor binding of AII were performed by using vascular (mesenteric artery) as well as nonvascular (uterus) smooth muscle. Small intestines with attached mesenteries were removed en bloc from control or potassium-deficient animals and placed in iced phosphate-buffered saline (PBS). Using an adaptation of the method of Kwan et al. (12), the intestines were placed on a piece of filter paper moistened with $0.25 \mathrm{M}$ sucrose in a glass petri dish atop ice. The mesenteric arteries and branches were bluntly dissected away from veins, fat, and bowel by using a rubber policeman and fine forceps. Adherent fat was then removed from the arteries with a loose-fitting Potter Elvehjeim mechanical homogenizer, as described by Gunther et al. (13).

Uteri were prepared by using the technique of Rouzaire-Dubois et al. (14) as modified by Douglas (15). Uteri were bathed in chilled Tris$\mathrm{HCl}$ buffer ( $\mathrm{pH}$ 7.4) while adherent fat was removed and the serosa stripped. Pooled tissue from either source from four to eight rats was then suspended in $40 \mathrm{ml}$ Tris- $\mathrm{HCl}$, homogenized (Polytron model PT10ST, Brinkmann Instruments, Inc., Westbury, NY) for $25 \mathrm{~s}$, and sedimented at $1,000 \mathrm{~g}$ for $10 \mathrm{~min}$ at $4^{\circ} \mathrm{C}$. The supernatant was centrifuged at $100,000 \mathrm{~g}$ for $35 \mathrm{~min}$. The resulting pellet, a fraction rich in plasma membrane (14), was resuspended in $1.5 \mathrm{ml}$ Tris- $\mathrm{HCl}$ with a Potter Elvehjem homogenizer. Measurements of uterine suspension 5'-nucleotidase activity (16), a plasma membrane enzyme, showed equal activities in both control and potassium-deficient receptor suspensions (30.9 \pm 4 vs. $30.4 \pm 3.6 \mu \mathrm{mol} / \mathrm{h}$ per milligram of protein, $n=3$ ). 
Receptor binding. All experiments were performed within $3 \mathrm{~h}$ of removal of tissue and on each day, receptors from both control and potassium-deficient rats were studied. Incubations were performed in $50 \mathrm{mM}$ Tris- $\mathrm{HCl}$ (pH 7.4) with $0.8 \%$ bovine serum albumin, $120 \mathrm{mM}$ $\mathrm{NaCl}, 10 \mathrm{mM} \mathrm{MgCl}, 5 \mathrm{mM}$ dithiothreitol, and 50-200 $\mu \mathrm{g}$ receptor protein. 5-25 pg of ${ }^{125}$ I-AII (New England Nuclear, Boston, MA; sp act $1880 \mu \mathrm{Ci} / \mathrm{mg})$ and varying amounts of unlabeled AII $\left(10^{-10}-10^{-8} \mathrm{M}\right)$ (Beckman Instruments, Inc., Fullerton, CA) were added to the incubation tubes to perform binding inhibition studies. Nonspecific binding was determined in the presence of $0.3 \mu \mathrm{M}$ unlabeled AII. Total incubation volume was $300 \mu \mathrm{l}$. Binding studies were performed at $25^{\circ} \mathrm{C}$ for 40 min. Receptor-bound AII was separated from free AII by filtration on Millipore filters (HAWP $0.45 \mu \mathrm{m}$, Millipore Corp., Bedford, MA) after binding was terminated by addition of $4 \mathrm{ml}$ iced PBS to the incubation tube. Receptor-bound radioactivity trapped on filters was counted on a Searle gamma counter (G. D. Searle \& Co., Skokie, IL) with $63 \%$ counting efficiency. All studies were performed in duplicate or triplicate, and binding data was corrected for nonspecific binding (mesenteric arteries $<16 \%$ of total binding; uterus $<40 \%$ of total binding). Specific binding was $1.5-3.5 \%$ of total radioactivity for uterus and $5-12 \%$ of total radioactivity for mesenteric arteries.

Binding constants were determined by Scatchard analysis of binding data (17) after fitting data to a line by using the least-squares method (18). Protein concentration of the receptor suspension was determined by a modification of the method of Lowry et al. (19).

Results are expressed as mean \pm standard error. Statistical comparisons were made by unpaired $t$ test (18). Linear regression of the dose-response data was performed by the least-squares method. Slopes for the doseresponse curves were compared by unpaired $t$ test.

\section{Results}

Effects of potassium-deficient diet. At the time of the study, plasma potassium was $3.95 \pm 0.13 \mathrm{meq} / \mathrm{liter}$ in control rats and $2.12 \pm 0.09 \mathrm{meq} / \mathrm{liter}$ in potassium-deficient rats $(P<0.001)$. Previous studies from our laboratory using the identical diet have shown significant decreases in muscle and kidney potassium content after 14-21 d of this potassium-deficient diet (4). Plasma renin activity was $11.48 \pm 2.2 \mathrm{ng} \mathrm{AI} / \mathrm{ml}$ per hour in potassiumdeficient rats compared with $3.81 \pm 0.62 \mathrm{ng} \mathrm{AI} / \mathrm{ml}$ per hour in control rats $(P<0.02)$.

Hemodynamic studies. Basal MAP was $113.1 \pm 2.1 \mathrm{mmHg}$ in control rats and $106.9 \pm 1.3 \mathrm{mmHg}$ in potassium-deficient rats $(P<0.025)$. The pressor response to graded doses of AII in control and potassium-deficient rats is shown in Fig. 1. The pressor response of potassium-deficient rats was $\sim 50 \%$ less than the pressor response of control rats receiving the identical doses of AII. In addition, the slope of the dose-response curve for potassium-deficient animals was significantly less than that for control animals $(P<0.001)$. Moreover, while the threshold dose for a significant pressor response to AII occurred between 2.5 and $5 \mathrm{ng}$ (pressor response, $2.7 \pm 0.8$ and $8.0 \pm 0.7 \mathrm{mmHg}$, respectively) in control rats, the threshold dose for potassiumdeficient rats was greater. A significant response was not seen until the AII dose was between 5 and $12.5 \mathrm{ng}$ (pressor response, $2.0 \pm 0.8$ and $6.4 \pm 1.0 \mathrm{mmHg}$, respectively).

Fig. 2 demonstrates the pressor response to graded doses of norepinephrine in control and potassium-deficient rats. In con-

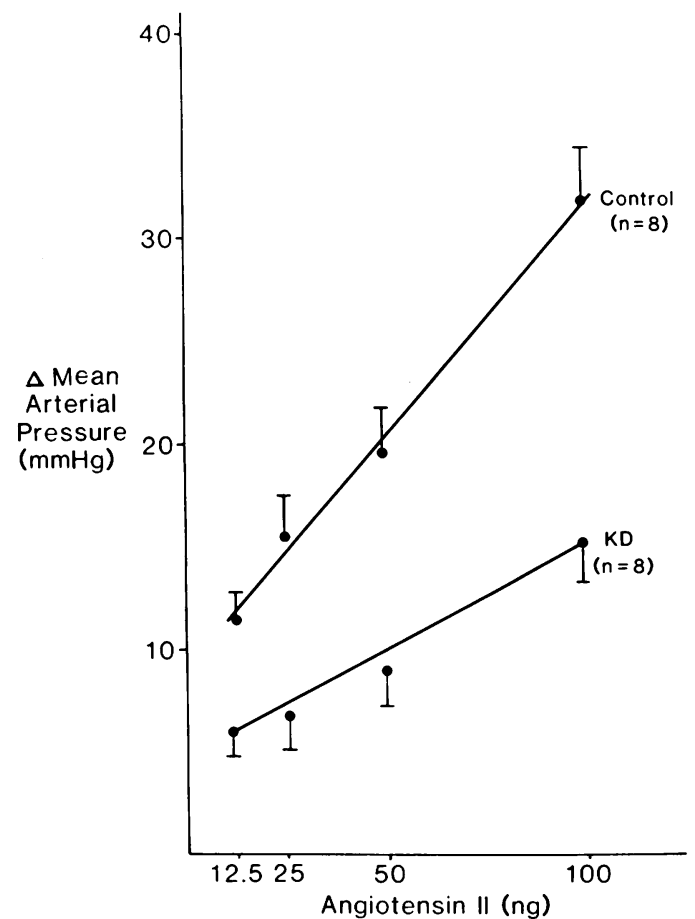

Figure 1. Pressor response to AII in control and potassium-deficient (KD) rats. KD vs. control, $P<0.005$ for all points except $100 \mathrm{ng}, P$ $<0.001$.

trast to the decreased pressor sensitivity of potassium-deficient rats to AII, there was no difference in the pressor response to norepinephrine in potassium-deficient animals in either the absolute changes in MAP or the slope of the dose-response curve.

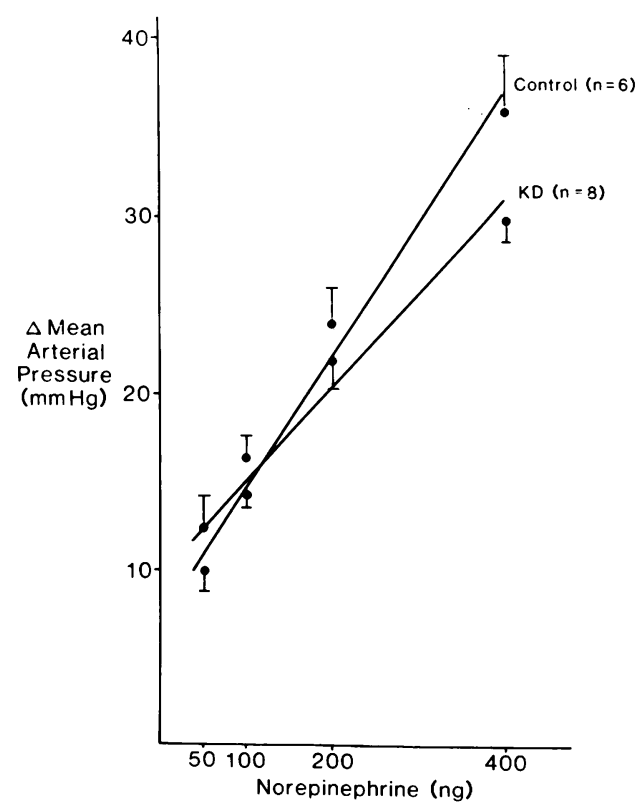

Figure 2. Pressor response to norepinephrine in control and potassium-deficient $(\mathrm{KD})$ rats. $\mathrm{KD}$ vs. control, no significant difference for any point. 
Since the pressor response to norepinephrine was normal in potassium deficiency, the data suggest that the decreased pressor effect of AII was not the result of a generalized defect in vascular smooth muscle responsiveness, but rather that the defect was specific for AII.

To determine whether prior receptor occupancy with endogenous AII was the cause for the diminished pressor sensitivity to exogenous AII, rats were pretreated with the converting enzyme inhibitor, teprotide. Sodium depletion resulted in a decrease in pressor response to AII which was corrected after the administration of teprotide. After administration of teprotide, MAP decreased in both control $(109.5 \pm 2.9$ to $107.1 \pm 3.7 \mathrm{mmHg}$; NS) and potassium-deficient rats (105.3 \pm 2.3 to $98.8 \pm 5.8 \mathrm{mmHg}$; NS). In contrast to the results in sodium depletion, the pressor response to AII remained abnormal in potassium-deficient rats treated with teprotide (Fig. 3). These results suggest, therefore, that while receptor occupancy with endogenous AII may mediate the decreased pressor response to exogenous AII in sodium depletion, the mechanism of the decreased pressor response to AII in potassium deficiency is independent of receptor occupancy with endogenous AII.

Because vasodilatory prostaglandins have been postulated to alter AII vascular responsiveness in hypokalemic dogs (7) and in hypokalemic man with Bartter's syndrome (20), we determined the role of vasodilatory prostaglandins in potassiumdeficient rats. Pretreatment of potassium-deficient and control

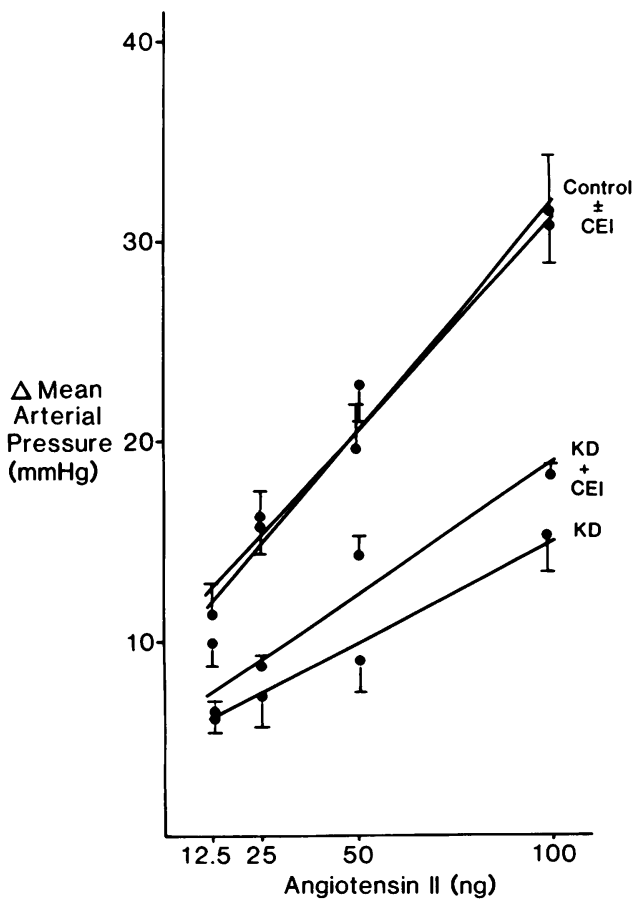

Figure 3. Pressor response to AII in control and potassium-deficient (KD) rats after pretreatment with the converting enzyme inhibitor (CEI) SQ20881. $n=8$ in each group. KD vs. $\mathrm{KD}+\mathrm{CEI}$, no significant difference for slope or any point except $50 \mathrm{ng}, P<0.05$. Control + CEI vs. KD + CEI, $P<0.001$ for all points except 12.5 ng, $P<0.025$. rats with the cyclooxygenase inhibitor, indomethacin, in doses which lowered urinary prostaglandin $\mathrm{E}_{2}$ excretion to $13 \%$ of basal values (4) did not alter the pressor response to AII in either potassium-deficient or control rats (Fig. 4). Since the vasodilatory prostaglandin, prostacyclin, also depends on the formation of endoperoxides for its synthesis, the results suggest that vasodilatory prostaglandins did not cause the decreased sensitivity to AII in potassium-deficient rats.

Receptor binding. Since potassium deficiency has been demonstrated to alter angiotensin receptors in the adrenal gland (21), we determined the effect of potassium deficiency on AII receptor-binding constants in smooth muscle. For both mesenteric artery and uterus steady-state binding data, when analyzed by Scatchard analysis, showed a single class of receptors with high affinity in all individual experiments. Binding was saturable and was linear in both control and potassium deficiency over a range of protein concentration of 50-250 $\mu \mathrm{g}$ protein/ $300 \mu \mathrm{l}$ incubation volume. Time course studies showed maximal binding occurred in both groups between 30 and $45 \mathrm{~min}$.

In the mesenteric artery, specific binding of AII increased as AII concentration increased. Binding of AII was equal or greater by potassium-deficient mesenteric arteries than control at all concentrations of AII (Fig. 5). Scatchard analysis showed a significant decrease in receptor affinity for AII in potassium deficiency. A representative Scatchard plot from a single experiment (Fig. 6) shows a marked difference in slope (and therefore, equilibrium dissociation constant $\left[K_{\mathrm{d}}\right]$ ) of AII binding in

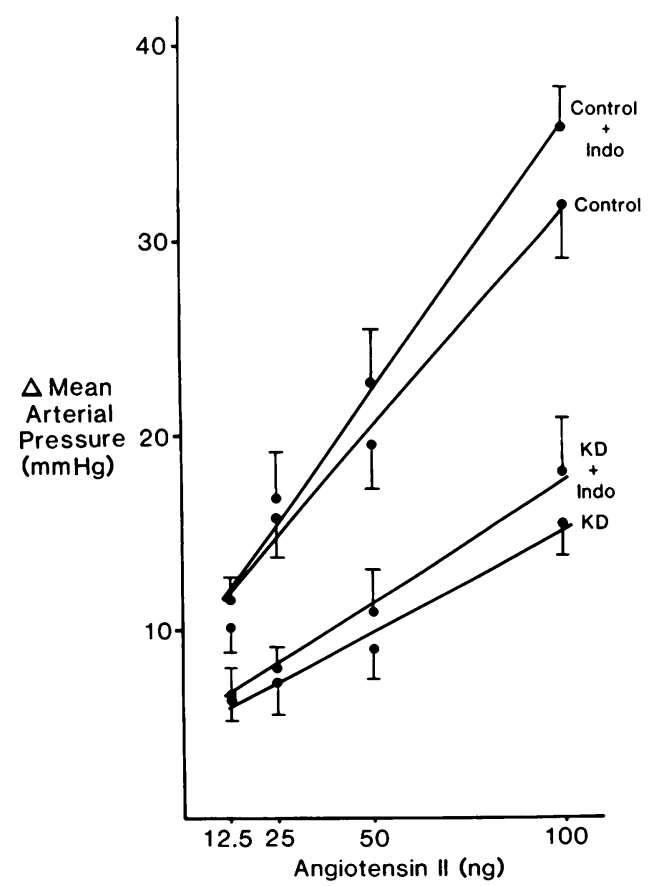

Figure 4. Pressor response to AII in Control and potassium-deficient $(K D)$ rats after pretreatment with indomethacin (Indo). $n=6$ in each group. Control vs. Control + Indo, no significant difference; KD vs. $\mathrm{KD}+$ Indo, no significant difference. 


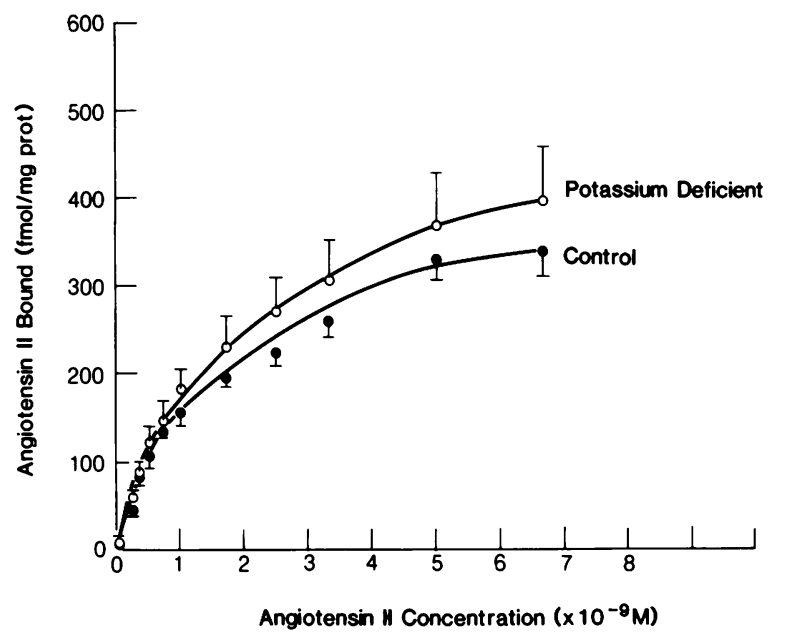

Figure 5. Angiotensin binding by mesenteric artery membranes from control and potassium-deficient animals. Each point represents mean specific binding from five separate experiments.

control and potassium-deficient animals. Table I shows mean $K_{\mathrm{d}}$ and receptor number from five experiments. Potassium deficiency resulted in marked changes in receptor-binding constants. Receptor affinity was reduced since $K_{d}$ increased by $42 \%$. It was anticipated that receptor number would also be diminished since potassium deficiency increases PRA, and since increases in AII have been demonstrated by us (Paller, M., and S. Linas. Unpublished data.) as well as others $(22,23)$ to decrease smooth muscle AII receptor number. In fact, despite marked increases in PRA, receptor number was increased in potassium deficiency. The increase in receptor number in potassium deficiency was

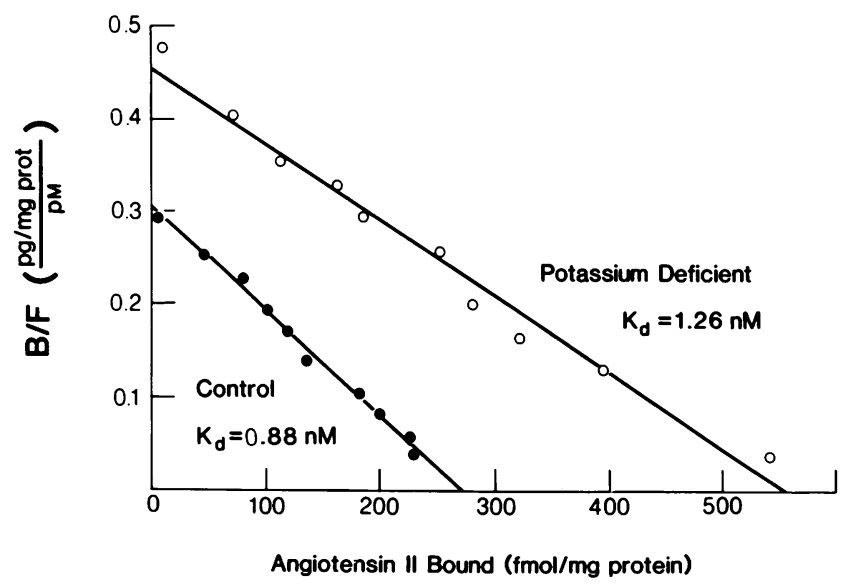

Figure 6. Scatchard analysis of vascular smooth muscle binding of ${ }^{125}$ I-AII. Values are the mean of duplicate determinations from a single experiment. Smooth muscle receptors from control animals bound $273 \mathrm{fmol} / \mathrm{mg}$ protein compared with $570 \mathrm{fmol} / \mathrm{mg}$ protein from potassium-deficient animals.
Table I. Mesenteric Artery AII Receptors in Potassium Deficiency

\begin{tabular}{llll}
\hline & $\begin{array}{l}\text { Control } \\
(n=5)\end{array}$ & $\begin{array}{l}\text { K deficiency } \\
(n=5)\end{array}$ & $P$ \\
\hline $\begin{array}{l}K_{\mathrm{d}}(n M) \\
\text { Receptor No. } \\
(\text { fmol } / \text { mg protein })\end{array}$ & $0.973 \pm 0.03$ & $1.39 \pm 0.09$ & $P<0.005$ \\
& $316 \pm 19$ & $470 \pm 75$ & $0.05<P<0.1$ \\
\hline
\end{tabular}

proportional to the decrease in affinity and resulted in no decrease in total binding of AII.

Studies of AII binding the uterine smooth muscle from control and potassium-deficient rats yielded similar results. Table II summarizes these findings. Potassium deficiency resulted in a significant decrease in affinity (57\% increase in $K_{d}$ ) and a twofold increase in receptor number. At higher concentrations of AII, binding was actually greater by potassium-deficient smooth muscle membranes (Fig. 7).

\section{Discussion}

While it has been known for many years that chronic potassium deficiency blunts the pressor effect of exogenous AII (5-9), the mechanism of this effect has not been extensively studied. In the present study, we have systematically evaluated several possible mechanisms which could have explained the decreased pressor response to AII in potassium deficiency.

Generalized defect in vascular smooth muscle. Although in vitro studies of isolated arterial segments demonstrate a requirement for small quantities of potassium for vascular smooth muscle to contract in response to pressor hormones (24), the decreased pressor response to AII in intact chronic potassiumdeficient rats is not mediated by a generalized vascular smooth muscle defect. In this regard, since the pressor response to another vascular constrictor, norepinephrine, was preserved in potassium-deficient animals, the decreased pressor response to AII is specific for angiotensin. While some investigators have found that the pressor effect of norepinephrine is maintained in potassium deficiency (7), this has not been a universal finding (5). It is likely, however, that the differences between these results relates to the fact that studies showing a decreased pressor effect of norepinephrine have been performed in anesthetized animals

Table II. Uterine Smooth Muscle AII Receptors in Potassium Deficiency

\begin{tabular}{lccc}
\hline & $\begin{array}{l}\text { Control } \\
(n=6)\end{array}$ & $\begin{array}{l}\text { K deficiency } \\
(n=6)\end{array}$ & $P$ \\
\hline $\begin{array}{l}K_{\mathrm{d}}(n M) \\
\begin{array}{l}\text { Receptor No. } \\
(\text { fmol/mg protein })\end{array}\end{array}$ & $3.82 \pm 0.44$ & $6.00 \pm 0.75$ & $<0.05$ \\
& $147.7 \pm 20.3$ & $307.9 \pm 35.3$ & $<0.005$
\end{tabular}




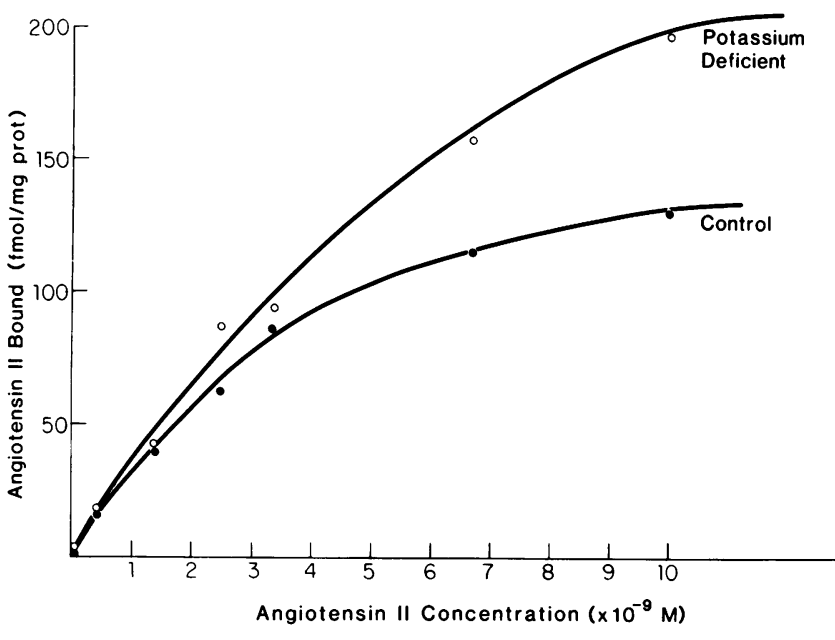

Figure 7. Angiotensin binding by uterine smooth muscle membranes from control and potassium-deficient animals in a single experiment. Amount of AII bound has been corrected for nonspecific binding.

(5). Since anesthesia itself can alter systemic hemodynamics (25), the preservation of norepinephrine sensitivity in our studies may be attributable to the use of conscious animals.

Changes in sodium balance. Although sodium depletion has been shown to decrease the vascular response to AII (11, $26,27)$, several studies have shown that the potassium-deficient rat is not sodium depleted. In our own studies (Paller, M., and S. Linas. Unpublished data.) and those by Sealey et al. (1), rats maintained on a potassium-deficient diet were in more positive sodium balance than rats on a normal potassium diet. Moreover, in contrast to sodium-depleted animals, we have found that both plasma volume and cardiac output are increased in the potassium-deficient rat (4).

Prior receptor occupancy. Since the pressor response to exogenous AII is dependent on the interaction of exogenous AII with its vascular receptor, the response to exogenous hormone would be expected to be diminished if the receptor sites were occupied by endogenous AII. This mechanism for decreased angiotensin vascular response has been postulated to occur during chronic sodium depletion (11). Since PRA and endogenous AII levels are increased in potassium as well as sodium-depleted rats (21), we examined the possibility that prior AII receptor occupancy was responsible for the decreased effect of exogenous AII. In this study, prior receptor occupancy by endogenous AII did not appear to be the mechanism for the decreased pressor response to AII in potassium deficiency.

Vasodilatory prostaglandins. Vasodilatory prostaglandins have been demonstrated to attenuate the pressor response to AII in normal (28) and sodium-depleted subjects (29). Moreover, in cirrhosis (30) and Bartter's syndrome (20), which are conditions also characterized by resistance to AII, indomethacin treatment to decrease prostaglandin synthesis results in an improved pressor response to AII. The present study, like the recent study of Adamick et al. (9), demonstrates that vasodilatory prostaglandins do not mediate the decreased vascular response to AII in the potassium-deficient rat. Although these results in the potassium-deficient rat seem to be in contrast to those of Galvez et al. (7), who have shown that prostaglandin inhibition improved the vascular response to AII in the potassium-deficient dog, $\mathrm{PGE}_{2}$ excretion is increased in the potassium-deficient dog while $\mathrm{PGE}_{2}$ excretion has not been found to be increased in the potassium-deficient rat $(4,31)$. Other as yet undefined species differences might also exist.

Alterations in vascular AII receptors. While the effects of chronic changes in potassium balance on adrenal AII receptors have been extensively studied $(15,20,32)$, the effects of chronic potassium depletion on smooth muscle angiotensin receptors have not been reported. Smooth muscle from two sources was employed for studies of AII receptors. Mesenteric arteries were used because these vessels are reactive to AII and are representative of resistance vessels in the body (13). However, it is difficult to prepare large quantities of smooth muscle membranes from these vessels. For this reason, receptor binding of AII was also studied in uterine smooth muscle, a tissue employed with success in previous studies $(14,15,33,34)$. Uterine tissue is easier to prepare in large quantities, has receptor binding characteristics similar to rabbit aorta smooth muscle (33) and rat mesenteric artery (13), and responds to AII in vitro over the same dose range as does rabbit aorta (35). Moreover, there is excellent correlation between AII-binding inhibition potencies of many AII analogs using the uterine smooth muscle radioreceptor assay and either a rat pressor assay or isolated rabbit aortic strips (36). In the setting of sodium depletion, receptor changes in the uterus (37) are identical to those observed in mesenteric artery and bladder $(22,23)$ and quite different from those found in the adrenal gland (39).

In the present study, a decrease in sensitivity to the pressor effect of submaximal doses of exogenous AII in potassium-deficient rats was manifested by a rightward shift of the doseresponse curve (Fig. 1). In addition, the dose-response curve of potassium-deficient animals was less steep than that of the control animals. From this finding, it might have been predicted that the decreased sensitivity to AII in potassium-deficient animals was mediated by a decrease in affinity of AII receptors. The results obtained in the receptor-binding studies support this prediction in that they revealed a $35 \%$ decrease in AII receptor affinity.

A surprising finding in the present study was that, despite increased circulating levels of AII, potassium deficiency resulted in an increase in AII receptor number. Since an increase in angiotensin levels following low dose AII infusion $(23,34,39)$ or prolonged sodium depletion $(22,23)$ is usually associated with either no change (34) or a decrease, i.e., down regulation, in smooth muscle receptor number $(22,23,39)$, the results of the present study underscore the importance of potassium in altering regulation of AII receptor number. In this regard, Tables I and II demonstrate that despite high circulating levels of AII, AII receptor number was increased, not decreased, in the potassium-deficient rat. While the manner by which potassium regulates AII-binding constants is not known, possible mech- 
anisms include changes in receptor configuration induced by altered ionic composition of cellular constituents (33), indirect effects on plasma membrane structure via phospholipid compositional changes (40), and alterations of guanine nucleotide concentration (41). Further studies, however, will be required to determine which of these possibilities mediates the effects of potassium on AII receptors.

Although vascular AII receptors were found to have a greater affinity for AII and were present in greater number than in nonvascular tissue (uterus), potassium deficiency produced similar changes in both types of AII receptor. Affinity was decreased and receptor number increased in both mesenteric artery and uterus after potassium deficiency. A similar situation exists for sodium depletion where a decrease in AII receptor number has been demonstrated in mesenteric artery $(22,23)$ as well as bladder (23) and uterus (37). These results suggest that both vascular and nonvascular smooth muscle AII receptors are regulated by the same mechanisms.

Because the increase in receptor number in potassium deficiency was equivalent or greater than the decrease in receptor affinity, total binding of AII was not decreased in potassium deficiency (Figs. 5 and 7). This suggests that the decreased vascular response to AII in potassium deficiency is caused by a postreceptor defect. The site of this postreceptor defect is not known. Angiotensin does not activate adenylate cyclase (42), but does act through changes in intracellular calcium concentration $(43,44)$ and phosphorylation of contractile proteins $(45)$ Since the pressor response to norepinephrine (which also induces smooth muscle contraction via changes in intracellular calcium concentrations $[43,44])$ is intact, the defect appears to be proximal to the step where intracellular calcium concentration acts. Angiotensin does activate guanylate cyclase, but it is not clear whether changes in cyclic guanosine monophosphate mediate AII action (46). This or another step might be the site of the potassium deficiency-induced defect in vascular response. Further studies are needed to clarify the mechanism of action of AII on smooth muscle before the site of the potassium deficiencyinduced defect in smooth muscle response to AII can be elucidated.

Summary. Potassium deficiency results in decreased pressor sensitivity to AII. The decreased sensitivity to AII is not mediated by a generalized vascular smooth muscle defect, prior occupancy of AII receptors, or the presence of vasodilatory prostaglandins. Potassium deficiency does, however, result in a decrease in vascular smooth muscle AII receptor affinity, and despite increased circulating levels of AII, an increase in AII receptor number. Since total binding of AII is not decreased in potassium deficiency, a postreceptor defect mediates the decrease in pressor sensitivity to AII in the potassium-deficient rat.

\section{Acknowledgments}

The authors thank Dr. Jerrold M. Olefsky and Dr. Robert W. Schrier for their advice in the course of these studies, and Dr. Z. P. Horovitz for supplying SQ20,881. Mrs. Eileen Sutherland performed 5'-nucleo- tidase determinations and Miss Carolyn Bignall provided expert secretarial assistance.

This research was supported by the National Institutes of Health grants AM26156-02 to Dr. Linas, AM07135 and HL17871 to Dr. Paller, and HL22990 to Dr. Douglas.

\section{References}

1. Sealey J. E., I. Clark, M. B. Bull, and J. H. Laragh. 1970. Potassium balance and the control of renin secretion. J. Clin. Invest. 49:21192127.

2. Douglas, J., J. Hansen, and K. J. Catt. 1978. Relationships between plasma renin activity and plasma aldosterone in the rat after dietary electrolyte changes. Endocrinology. 103:60-65.

3. Freed, S. C., and M. Friedman. 1951. Depressor effect of potassium restriction on blood pressure of the rat. Proc. Soc. Exp. Biol. Med. 78:74-79.

4. Linas, S. L., and D. Dickmann. 1982. Mechanism of the decreased renal blood flow in the potassium depleted conscious rat. Kidney Int. 21:757-764.

5. Rosenmann, R. H., S. C. Freed, and M. Friedman. 1952. The peripheral vascular reactivity of potassium deficient rats. Circulation. 5:412-414.

6. Reid, W. D., and J. H. Laragh. 1965. Sodium and potassium intake, blood pressure, and pressor response to angiotensin. Proc. Soc. Exp. Biol. Med. 120:26-29.

7. Galvez, O. G., W. H. Bay, B. W. Roberts, and T. F. Ferris. 1977. The hemodynamic effects of potassium deficiency in the dog. Circ. Res. 40(Suppl. I):11-16.

8. Campbell, W. B., and J. M. Schmitz. 1978. Effect of alterations in dietary potassium on the pressor and steroidogenic effects of angiotensin II and III. Endocrinology. 103:2098-2104.

9. Adamick, R., M. E. Gold, S. Hayes, R. Coleman, J. T. McCreary, S. Sabatini, J. A. L. Arruda, and N. A. Kurtzman. 1981. Factors influencing vascular hyporesponsiveness to angiotensin II. Circ. Res. 49:932939.

10. Stockigt, J. E., R. D. Collins, and E. P. Biglieri. 1971. Determination of plasma renin concentration by angiotensin I immunoassay. Circ. Res. 28(Suppl. 2):175-191.

11. Thurston, H., and J. H. Laragh. 1975. Prior receptor occupancy as a determinant of the pressor activity of infused angiotensin II in the rat. Circ. Res. 36:113-117.

12. Kwan, C. Y., R. Garfield, and E. E. Daniel. 1979. An improved procedure for isolation of plasma membranes from rat mesenteric arteries. J. Mol. Cell. Cardiol. 11:639-659.

13. Gunther, S., M. A. Gimbrone, Jr., and R. W. Alexander. 1980. Identification and characterization of the high affinity vascular angiotensin II receptor in rat mesenteric artery. Circ. Res. 47:278-286.

14. Rouzaire-Dubois, B., M. A. Devynck, E. Chevillotte, and P. Meyer. 1975. Angiotensin receptors in rat uterine membranes. FEBS (Fed. Eur. Biochem. Soc.) Lett 55:168-172.

15. Douglas, J. G. 1979. Changes in potassium balance: inverse relationship between number and affinity of angiotensin II receptors of smooth muscle and adrenal target tissues. Am. J. Physiol. 237:E519E523.

16. Song, C. S., and O. Bodansky. 1967. Subcellular localization and properties of 5 '-nucleotidase in rat liver. J. Biol. Chem. 242:694699.

17. Scatchard, G. 1949. The attractions of proteins for small molecules and ions. Ann. NY Acad. Sci. 51:660-672.

18. Remington, R. D., and M. A. Schork. 1970. Statistics with Ap- 
plications to the Biological and Health Sciences. Prentice-Hall, Inc., Englewood Cliffs, NJ.

19. Lowry, A. H., N. J. Rosenbrough, A. L. Farr, and R. J. Randall. 1951. Protein measurements with the Folin phenol reagent. J. Biol. Chem. 193:265-275.

20. Horwitz, G., and H. S. Margolins. 1977. Bartter's syndrome: urinary prostaglandin $\mathrm{E}$-like material and kallikrein; indomethacin effects. Ann. Intern. Med. 87:281-286.

21. Douglas, J., and K. J. Catt. 1976. Regulation of angiotensin II receptors in the rat adrenal cortex by dietary electrolytes. J. Clin. Invest. 58:834-843.

22. Gunther, S., M. A. Gimbrone, Jr., and R. W. Alexander. 1980. Regulation by angiotensin II of its receptors in resistance blood vessels. Science (Wash. DC). 287:230-232.

23. Aguilera, G., and K. Catt. 1981. Regulation of vascular angiotensin II receptors in the rat during altered sodium intake. Circ. Res. 49:751-758.

24. Burks, T. F., C. T. Spalding, and V. D. Jones. 1971. Influence of sodium and potassium content on arterial responsiveness. Circ. Res. 29:525-533.

25. Linas, S. L., T. Berl, G. A. Aisenbrey, O. S. Better, and R. J. Anderson. 1980. The effect of anesthesia on hemodynamics and renal function in the rat. Pfluegers Arch. Eur. J. Physiol. 384:135-141.

26. Strewler, G. J., K. J. Hinrichs, L. R. Guiod, and N. K. Hollenberg. 1972. Sodium intake and vascular smooth muscle responsiveness to norepinephrine and angiotensin in the rabbit. Circ. Res. 31:758-766.

27. Slack, B. L., and J. M. Ledingham. 1976. The influence of sodium intake on the pressor response to angiotensin II in the unanesthetized rat. Clin. Sci. Mol. Med. 50:285-291.

28. Negus, P., R. L. Tannen, and M. J. Dunn. 1976. Indomethacin potentiates the vasoconstrictor actions of angiotensin II in normal man. Prostaglandins. 12:175-180.

29. Speckart, P., P. Zia, R. Zipser, and R. Horton. 1977. The effect of sodium restriction and prostaglandin inhibition of the renin-angiotensin system in man. J. Clin. Endocrinol. Metab. 44:832-837.

30. Zipser, R. D., J. C. Hoefs, P. F. Speckart, P. K. Zia, and R. D. Horton. 1979. Prostaglandins: modulators of renal function and pressor resistance in chronic liver disease. J. Clin. Endocrinol. Metab. 48:895900.

31. Hood, V. L., and M. J. Dunn. 1978. Urinary excretion of prostaglandin $\mathrm{E}_{2}$ and prostaglandin $\mathrm{F}_{2}$ in potassium deficient rats. Prostaglandins. 15:273-280.
32. Douglas, J. G. 1980. Potassium ion as a regulation of adrenal angiotensin II receptors. Am. J. Physiol. 239:E317-E321.

33. Devynck, M. A., and P. Meyer. 1976. Angiotensin receptors in vascular tissue. Am. J. Med. 61:758-767.

34. Rioux, F., W. K. Park, and D. Regoli. 1973. Application of drug-receptor theories to angiotensin. Can. J. Physiol. Pharmacol. 51:665672.

35. Douglas, J. G., M. Michailov, M. C. Khosla, and F. M. Bumpus. 1980. Comparative receptor-binding properties of heptapeptide and octapeptide antagonists of angiotensin II in rat adrenal glomerulosa and uterine smooth muscle. Endocrinology. 106:120-124.

36. Aguilera, G., R. L. Hauger, and K. J. Catt. 1978. Control of aldosterone secretion during sodium restriction: adrenal receptor regulation and increased adrenal sensitivity to angiotensin II. Proc. Natl. Acad. Sci. USA. 75:975-979.

37. Douglas, J. G. Effects of high potassium diet on angiotensin II receptors and angiotensin-induced aldosterone production in rat adrenal glomerulosa cells. Endocrinology. 106:983-990.

38. Devynck, M. A., B. Rouzaire-Dubois, E. Chevillotte, and P. Meyer. 1976. Variations in the number of uterine angiotensin receptors following changes in plasma angiotensin levels. Eur. J. Pharmacol. 40:2737.

39. Douglas, J. G., and G. P. Brown. 1982. Effect of prolonged low dose infusion of angiotensin II and aldosterone on rat smooth muscle and adrenal angiotensin II receptors. Endocrinology. 111:988-992.

40. McCaleb, M. L., and D. B. Donner. 1981. Affinity of the hepatic insulin receptor is influenced by membrane phospholipids. J. Biol. Chem. 256:11051-11057.

41. Glossman, H., A. Baukal, and K. J. Catt. 1974. Angiotensin II receptors in bovine adrenal cortex. Modification of angiotensin II binding by guanyl nucleotides. J. Biol. Chem. 249:664-666.

42. Baxter, J. D., and J. W. Funder. 1979. Hormone receptors. New. Engl. J. Med. 301:1149-1161.

43. Bohr, D. F. 1973. Vascular smooth muscle updated. Circ. Res. 32:665-672.

44. Deth, R., and C. van Breeman. 1977. Agonist induced release of intracellular $\mathrm{Ca}^{2+}$ in the rabbit aorta. J. Membr. Biol. 30:363-380.

45. Anderson, J. M., M. A. Gimbrone, Jr., and R. W. Alexander. 1981. Angiotensin II stimulates phosphorylation of the myosin light chain in cultured vascular smooth muscle cells. J. Biol. Chem. 256:46934696.

46. Vesely, D. L. 1981. Angiotensin II stimulates guanylate cyclase activity in aorta, heart and kidney. Am. J. Physiol. 240:E391-E393. 